\title{
Entrepreneurial Characteristics and Business Profile of Women Owned Small and Medium Enterprises (SMEs): A Case Study of the Tamale Metropolitan Area
}

\author{
Eva Atu Alhassan (Corresponding author) \\ Dept. of Planning, Kwame Nkrumah University of Science and Technology, Kumasi, \\ Ghana \\ E-mail: evaatu@yahoo.com
}

Mabel Akosua Hoedoafia

Faculty of Economics and Business Administration, Catholic University College of Ghana, Fiapre - Sunyani, Ghana

E-mail: mhoedoafia@yahoo.com

Elvis Adam Alhassan

Dept. of Mathematics, University for Development Studies, Navrongo, Ghana

E-mail: aelvis@uds.edu.gh

Received: January 24, 2016 Accepted: February 11, 2016 Published: June 6, 2016

doi:10.5296/bms.v7i1.8934 URL: http://dx.doi.org/10.5296/bms.v7i1.8934

\begin{abstract}
Despite the vital role of women entrepreneurs in the economic development of their families and countries, it has been revealed that they have low business performance compared to their male counterparts. In this paper, an analysis of the business profile and entrepreneurial characteristics of women owned Small and Medium Enterprises in the Tamale Metropolis has been carried out. A cross-sectional design was used to collect quantitative and qualitative data from a variety of women entrepreneurs. Women entrepreneurs who have benefited from
\end{abstract}




\section{Macrothink}

Business Management and Strategy ISSN 2157-6068 2016, Vol. 7, No. 1

microcredit were selected using simple random sampling. They were then categorized based on their economic activities. The study found that, the level of education of the respondents was generally low; over $69 \%$ had no formal education, $20 \%$ had primary education, $9.5 \%$ had secondary and $1 \%$ had tertiary education. Furthermore, $54.2 \%$ of the enterprises were managed by the entrepreneurs' themselves whiles $7.8 \%$ were run by the owner and other non-family employees. Also Only about $3 \%$ of the businesses surveyed were registered.

Keywords: Age dynamics, Educational level, Loan profile, SMEs, Business profile, Tamale 


\section{Introduction}

Since the 1980s, there have been consistent efforts to integrate women effectively into all development projects and programmes, to increase their access to education; skills training, credit and land, in order to enable them participate fully in economic activity. Also, there has been a growing recognition and elimination of certain structures and attitudes toward women in societies which impacted negatively on their ability to function as economic agents in society. Women had previously been wrongly perceived as a marginal economic group but have the potential as wealth creators (Stevenson \& St-Onge, 2005).

The World Bank (2001) revealed that the provision of sustainable employment to women enable them earn steadier wages which improved their development. In view of this, various agents such as the African Development Bank (AfDB), the International Labour Organization (ILO), the International Finance Corporation (IFC), the World Bank and more recently the Government of Ghana, have put in place several interventions to address challenges faced by women in their efforts to actively participate in the productive economy, thereby tapping into their potential for economic growth. Supporting women's entrepreneurship has been identified as very vital to family well-being because they do not only support themselves but also their families with the income they receive. Women owned SMEs thus contribute significantly to the development of the economy. Other advantages for supporting women enterprises are that, it helps the entrepreneurs to gain self-reliance, self-esteem and improves their decision making abilities. It also offers them greater control over their social and economic lives (Kantor, 2001).

SMEs can generate the desired effects/results only when entrepreneurs leave the informal economy and rather operate in the formal sector. Unfortunately, high taxes coupled with unfavourable business environment, bureaucracy and corruption hinders the prospects and successes of SMEs (OSCE, 2006). These challenges impede the development and growth of SMEs and their subsequent contribution to the national economy especially that of women owned enterprises in Sub-Saharan African (SSA). Also, several gender specific constraints further impede the entrepreneurial development of women. These include limited access to credit and other useful resources; less freedom in selecting sectors to operate in, less time and opportunity to attain higher education needed for successful entrepreneurship. These constraints hinder women entrepreneurial growth as compared to their male counterparts as they are the worse affected owing to the different societal roles and responsibilities assigned to them.

In this work, the entrepreneurial characteristics and business profile of women owned Small and Medium Enterprises (SMEs) in the Tamale metropolitan area in Ghana has been studied and presented. The profiles include age dynamics, household size, educational level, marital status of the women entrepreneurs, registration of business, loan profile among others. The rest of the paper is organized as follows: the next section reviews the relevant literature; section three presents the methodology while the results are discussed in section four. The conclusion is captured in section five. 


\section{Literature Review}

SMEs have been defined differently worldwide. The European Union (EU) defines companies employing fewer than 10 employees as microenterprises, those with more than 10 but fewer than 50 employees as a small enterprise whilst those with more than 50 but less than 250 employees as a medium enterprise. On the other hand, the United States refers to businesses with fewer than 100 employees as small, while medium-sized business often refers to those with more than 100 employees but fewer than 500 employees. In Canada, a small business is a business with less than 100 employees (if the business is a goods-producing business) or fewer than 50 employees (if the business is a service-based business), whilst a medium sized business should have more than 100 employees but less than 500 employees (Carsamer, 2009).

In Ghana various definitions have been given for Micro, Small and Medium scale enterprises based on several criteria but the most commonly used criterion is the number of employees of the enterprise (Kayanula and Quartey, 2000). However, the National Board for Small Scale Industries' definition of SMEs is based on "fixed asset and number of employees". It therefore defines Small enterprises as those "enterprises employing between 6 and 29 workers or have fixed assets not exceeding 100,000 USD, excluding land and building" and medium enterprises as those employing between 30 and 99 workers or have fixed assets not exceeding 1,000,000 USD, excluding land and building (NBSSI, 2013). Contrary to the NBSSI, the Ghana Statistical Service (GSS) regard firms with less than 10 employees as small-scale enterprises and their counterparts with more than 10 employees as medium and large-sized enterprises. The value of fixed assets in the firm has also been used as an alternative criterion for defining $\mathrm{SME}^{\mathrm{ee}} \mathrm{s}$. The Regional Project on Enterprise Development in the Ghana Manufacturing Survey Paper grouped firms into 4 categories as: (i) micro enterprise, less than 5 employees; (ii) small enterprise, 5 -29 employees; (iii) medium enterprise, 30 - 99 employees; and (iv) large enterprise, 100 and more employees (Teal, 2002).

According to Osei-Boateng and Ampratwum (2011), 80 percent of the Ghanaian workforce is employed in the informal sector. The ease of entry and exit in the informal sector has provided an employment opportunity to the growing number of people in the urban areas (Garcia-Bolivar, 2006; Bacchetta et al., 2009). The informal sector according to the International Labour Organisation (ILO) provides employment for about 61 per cent of the urban labour force in developing countries of which majority are women (Akintoye, 2008; ILO, 2000). Similarly, in Ghana, women's participation in informal sector employment was estimated at 53.3 percent in 2005. These statistics imply that the informal sector in developing countries is a major source of livelihood to the increasing labour force (Akintoye, 2006; Ghana Statistical Service, 2005).

The informal sector in Ghana is made up of micro and small-scale enterprises. It consists of producers, wholesalers, retailers and consumers and the workers are largely self-employed (Osei-Boateng and Ampratwum, 2011). The sector consists of varied activities and covers a wide range of enterprises including individual home-based and manufacturing, petty trading, 
and street merchants. In rural Ghana, informal sector work mainly involves agriculture $(75 \%)$ (GSS, 2008) whiles that of urban workers, $43 \%$ are engaged in non-agricultural activities. Osei-Boateng and Ampratwum, (2011) argued that informal sector workers escape the regulation of government and as such suffers neglect of policy makers. Their escape has also culminated in evasion of their civil responsibilities such as tax payment and other responsibilities associated with their work due to the fact that many of the enterprises in the sector are unregistered. They also assert that most women in urban areas who are predominantly illiterate or semi-illiterate engage in economic activities such as food trading and processing, hairdressing and dressmaking. They acquire their knowledge and skills largely from family and friends.

In various African countries, the share of women in micro and small enterprises is relatively high: 65 percent in Ethiopia, 48 percent in Kenya, 43 percent in Tanzania and 67 percent in Zimbabwe. However, a number of women owned enterprises do not grow beyond the micro-level of five employees (Kiraka et al., 2013). This characterises the SME sector in general, but it is more evident among women-owned enterprises (Marcucci, 2001; Stevenson and St-Onge 2005). So the challenge in Africa is less about trying to increase the number of women entrepreneurs and more about how to legitimize and strengthen the base of their activity so they can grow the enterprises as already indicated elsewhere. Several studies on women entrepreneurship have identified numerous constraints facing them. In particular, issues relating to employment generation, conditions of service and market expansion, and growth from micro to small, and to medium size, have been dominant. Thus over the years, there have been studies centred on identifying policies, programmes and actions that positively and directly impact on new start up creation as well as job creation in both new and existing women-owned enterprises. To add to the literature in this direction, we examined the effects of microcredit on the profitability of women owned enterprises as well as the challenges they face (see Alhassan, Hoedoafia \& Braimah, 2016) for further details.

Roomi and Parrot (2008) found in a study that women entrepreneurs do not enjoy the same opportunities as men due to some discriminatory sociocultural values and customs such as the inherent attitudes of a patriarchal society where men tend to be superior to women, which limits women's access to capital, land, business premises, information technology, training and agency assistance. Women also receive little encouragement from some male family members. They suggested that in order to foster development, multi-agency cooperation is required. The media, educational policy makers and government agencies should combine efforts in providing women with improved access to business development services and also facilitate local, regional and national networks.

\section{Methodology}

\subsection{Study Area}

The Tamale Metropolis is located in the central part of the Northern Region and is bounded by Sagnarigu District to the North, Mion District to the East, Tolon District to the West, 


\section{Macrothink Institute ${ }^{T M}$}

Central Gonja to the South West and East Gonja to the South. Geographically, the Metropolis lies between latitude $9^{\circ} 16^{\prime \prime}$ and $9^{\circ} 34^{\prime \prime}$ North and longitudes $0^{\circ} 36^{\prime \prime}$ and $0^{\circ} 57^{\prime \prime}$ West.

The Metropolis has a total estimated land size of $550 \mathrm{~km} \mathrm{sq}$. (MoFEP, 2014). According to the 2010 population and housing census, the Metropolis had in 2010 a total population of 371,351 with males constituting 185,995 and females 185,356 (GSS, 2012).

\subsection{Sampling and Data Collection}

The study employed a cross-sectional design to collect data on relevant variables from a variety of women entrepreneurs. The population of the study was all women entrepreneurs who have accessed credit from selected Microfinance Institutions (MFIs) and the units of analysis were women entrepreneurs who are beneficiaries of microcredit from the MFIs. The study used simple random sampling technique to select women entrepreneurs from sampled MFIs who have benefited from microcredit. Stratified sampling was then used to categorize the women based on the economic activities they are engaged in. A mathematical sampling formula by Yamane (1967) was used to determine the sample size and from the calculation the sample size was 202. One hundred and ninety-nine respondents were however interviewed. Data was obtained from both primary and secondary sources. Primary data was obtained using semi-structured and structured questionnaires while secondary data was obtained from journals, articles and research studies. Both quantitative and qualitative data were collected for the study. For the qualitative part of the work, semi structured interviews were used while for quantitative data, semi-structured questionnaires were used. The data was collected from the owners or managers of all the sampled SMEs. The data generated through the questionnaires were analysed using the Statistical Package for the Social Sciences (SPSS) Version 20 and Microsoft Excel tools.

\section{Results and Discussions}

\subsection{Age Dynamics of Women Entrepreneurs}

In Figure 1, the age range of the entrepreneurs is presented.

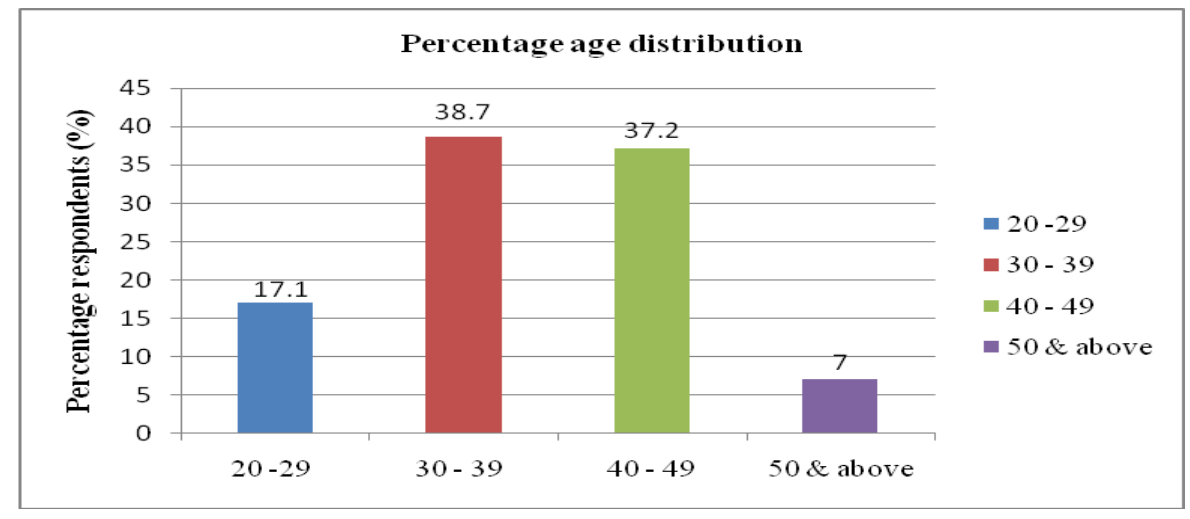

Figure 1. Age dynamics of women entrepreneurs

Source: Authors Construct. 


\section{Al Macrothink}

Business Management and Strategy

ISSN 2157-6068 2016, Vol. 7, No. 1

The results of the survey indicate that the age of respondents ranged between 20 and 50 \& above years. Majority of the respondents were aged between 30-39 years whilst only 7\% of them were aged 50 years and above. The ages of the respondents indicate that; a high number of young women are involved in active economic activities. Even though the credit schemes did not actually place any ban on age, the results revealed that only $7 \%$ of the entrepreneurs were aged 50 years and above.

\subsection{Educational Level of Entrepreneurs}

The educational levels of the entrepreneurs are presented in table 1 below. From the table, it can be observed that, the level of education of the participants is generally low.

Table 1. Educational level of entrepreneurs

\begin{tabular}{|l|l|l|}
\hline Educational level & Frequency & Percent \\
\hline No Education & 138 & 69.3 \\
\hline Primary & 40 & 20.1 \\
\hline Secondary & 19 & 9.5 \\
\hline Tertiary & 2 & 1.0 \\
\hline Total & 199 & 100.0 \\
\hline
\end{tabular}

Source: Authors Construct

Over 69 percent of the respondents had no formal education, only 20 percent had primary education, 9.5 percent had secondary and 1 percent had tertiary education. The low educational profile of the respondents may account for the poor business record keeping. This may also explain why the design of the micro credit facilities requires limited documentation on the part of the recipient.

\subsection{Marital Status of Women Entrepreneurs}

In table 2 below, the marital status of the respondents is presented.

Table 2. Marital status of women entrepreneurs

\begin{tabular}{|l|l|l|}
\hline Marital status & Frequency & Percent \\
\hline Married (Monogamy) & 94 & 47.2 \\
\hline Married (Polygamy) & 80 & 40.2 \\
\hline Widowed & 16 & 8.0 \\
\hline Single & 7 & 3.5 \\
\hline Separated & 2 & 1.0 \\
\hline Total & 199 & 100.0 \\
\hline
\end{tabular}

\section{Source: Authors Construct}

It can be seen from the table that, $87.4 \%$ of them were married; ninety-four of the respondents representing $47.2 \%$ were in monogamous marriages whilst $40.2 \%$ were in 


\section{Macrothink}

Business Management and Strategy

ISSN 2157-6068 2016, Vol. 7, No. 1

polygamous marriages. The high number of respondents married may suggest the readiness of women in contributing to their household income.

\subsection{Household Size of Women Entrepreneurs}

Table 3 below shows the household size of all respondents. The GSS (2005) defines household as a person or groups of persons who live together in the same house or compound, share the same housekeeping arrangements and are catered for as one unit.

Table 3. Household size of women entrepreneurs

\begin{tabular}{|l|l|l|}
\hline Household size & Frequency & Percent \\
\hline $1-4$ & 49 & 26.1 \\
\hline $5-8$ & 100 & 53.2 \\
\hline $9-12$ & 21 & 11.2 \\
\hline $13 \&$ above & 18 & 9.6 \\
\hline Total & 188 & 100.0 \\
\hline Unstated & 11 & \\
\hline Sample & 199 & \\
\hline
\end{tabular}

\section{Source: Authors Construct}

The average household size of 7 representing 53\% of respondents was higher than the mean household size in Ghana of 4.3 as reported by the Ghana Living Standard Survey, GLSS (2000). The increase in household size compared to the national figure could be attributed to the polygamous nature of respondents or the improvement of their economic status which makes them able to cater for large households. In the survey, about $26.1 \%$ of the women respondents had household sizes of 1-4, while $53.2 \%$ registered household sizes of 5-8.

\subsection{Business Profile of Respondents}

\subsubsection{Formal Registration Status of Business}

Figure 2 shows the formal registration status of the SMEs. From the figure, it can be observed that only about $3 \%$ of the businesses surveyed were registered. This could pose a serious challenge to government in the collection of taxes. 


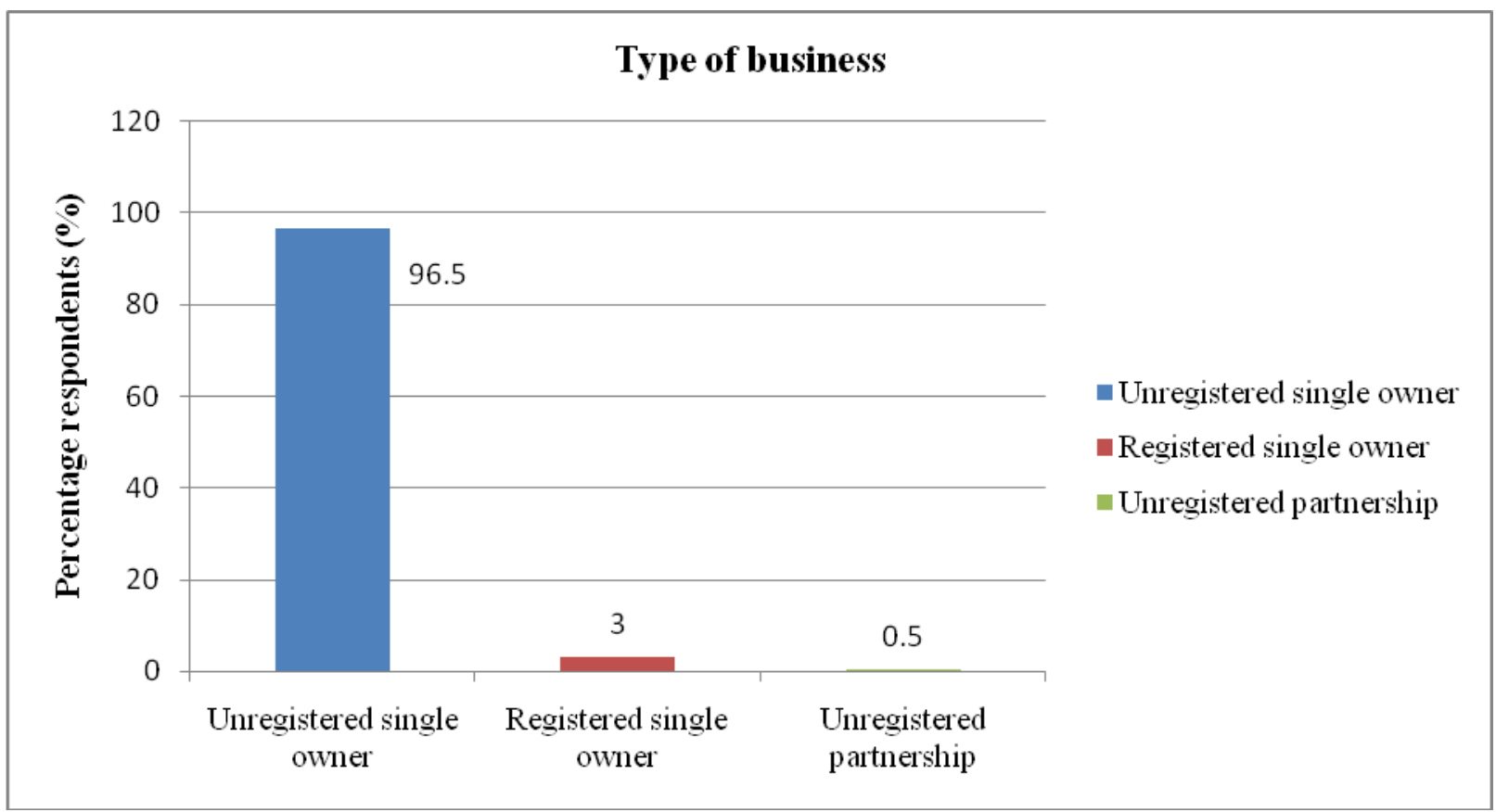

Figure 2. Formal registration status of business

Source: Authors Construct.

Most of the businesses encountered were operated by single owners and they all fell under the informal sector. This confirms the assertion that micro credit facilities are geared toward supporting the informal sector of the economy.

\subsubsection{Kinds of Business}

Micro enterprise is an enterprise that employs less than five employees (Teal, 2002).

Table 4. Kinds of business

\begin{tabular}{|l|l|l|}
\hline Business Type & Frequency & Percent \\
\hline Micro enterprise & 198 & 99.5 \\
\hline Small enterprise & 1 & 0.5 \\
\hline Total & 199 & 100 \\
\hline
\end{tabular}

Source: Authors Construct.

From the survey results as presented in table 4, 99.5\% of the enterprises were classified as micro enterprises. The study data agrees with Kiraka et al., (2013) that a number of women owned enterprises do not grow beyond the micro-level of five employees, if they grow at all.

\subsubsection{Economic Activities undertaken by Respondents}

The main activities of the women are presented in Table 5. Petty trading accounted for more than $86 \%$ of the main activities undertaken by the respondents while only $4 \%, 3 \%, 4 \%$ and 
$2.5 \%$ were involved in agro processing, bakery, dress making and hair dressing respectively as can be seen in table 5 .

Table 5. Economic activities undertaken by respondents

\begin{tabular}{|l|l|l|}
\hline Economic activities & No & Percent \\
\hline Petty Trading & 172 & 86.5 \\
\hline Agro processing & 8 & 4 \\
\hline Bakery & 6 & 3 \\
\hline Dress making & 8 & 4 \\
\hline Hair dressing & 5 & 2.5 \\
\hline Total & 199 & 100 \\
\hline
\end{tabular}

Source: Authors Construct

The high percentage of respondents in trading activities confirms the findings of Aryeetey et al. (2000), that women have been active players in the area of trading since Ghana's independence.

\subsubsection{Management of Micro Enterprises in Tamale metropolis}

In table 6, the management types of micro enterprises in the Tamale metropolis are presented.

Table 6. Management of micro enterprises in Tamale metropolis

\begin{tabular}{|l|l|l|}
\hline Management of Business & Frequency & Percent \\
\hline Self & 97 & 54.2 \\
\hline Self and family & 67 & 37.4 \\
\hline Self and other non-family employees & 14 & 7.8 \\
\hline Non-family employees & 1 & 0.6 \\
\hline Total & 179 & 100 \\
\hline
\end{tabular}

Source: Authors Construct

From the table, it can be observed that, ninety-seven respondents representing $54.2 \%$ of the enterprises were managed by the entrepreneurs' themselves whiles only $7.8 \%$ of the enterprises were run by the owner and other non-family employees. Job creation as noted by Voulgaris et al. (2003) is an important social goal and development objective to support small enterprises. Studies, which took employment as an indicator of enterprise growth, indicate that small firms are contributing to a greater degree towards the number of jobs created. This however contrasts the findings from this study. This may be attributed to the fact that a greater number of the businesses were micro enterprises.

\subsubsection{Reasons why Women go into Business}

Women go into business for numerous reasons. The following reasons were obtained from 
the survey:

i. Family and social demands: Heads of households cater for the needs of their families and bear the cost of domestic expenditure. Twelve percent of the respondents were identified to be heads of their households with no external support. On the basis of this, they had to optimize on business profits to support their families in areas such as health care, provision of education, clothing and food. The high level of polygamy in the study area also influenced most of the women to enter into business to support their large families.

ii. Socio-economic empowerment: microcredit according to Ghadoliya (2000) plays a crucial role in the socio-economic empowerment of individuals most especially women within households by promoting their participation in decision making at all levels. Similarly, Goetz and Sen (1994) and Mayoux (2005) posit that, the increase in income of women reduces their vulnerability to domestic violence and also helps them have a better control of their reproductive health. These views were confirmed from the study as the women noted that being economically empowered enables them to participate in household decision making and also reduces their vulnerability to domestic violence.

\subsection{Loan Profile}

\subsubsection{Administration of the Microcredit}

It was revealed from the study that operating an account with the chosen Micro Finance Institution (MFI) for a specified period was the primary requirement for obtaining a micro credit. Before the credit is disbursed, the entrepreneur is appraised by the credit officer to determine their repayment ability. After which the approved amount is paid into the clients account with the MFI. Processing and administrative fees are also charged on the amount of loan requested by the client. Credits were found to be given to clients either as individuals or in groups. At the group level the credit is disbursed by the credit officer who meets with the group weekly for collection of loans.

\subsubsection{Size of Loan Amounts}

More than $40 \%$ of the respondents received loans ranging between GHS 200-400 each as their first loans whilst $49.2 \%$ received between GHS 401-600 as shown in table 7 .

Table 7. Distribution of first loan received by respondents

\begin{tabular}{|l|l|l|}
\hline First Loan Received & Frequency & Percent \\
\hline $200-400$ & 80 & 40.2 \\
\hline $401-600$ & 98 & 49.2 \\
\hline $601-800$ & 2 & 1.0 \\
\hline $800 \&$ above & 19 & 9.5 \\
\hline Total & 199 & 100 \\
\hline
\end{tabular}

Source: Authors Construct. 
The loans received were generally small. This confirms the findings of Stevenson and St-Onge (2005) that the loan sizes from MFIs have tended to be too small to support growth. However, the assurances of getting bigger loans were based upon payment of previous loans. This served as a motivation to repay loans on time. From the survey conducted, $70.3 \%$ of respondents received subsequent loans between 1-17 times higher than previous amounts.

\subsubsection{Repayment Conditions}

Repayment of the loan usually started after a week or a month after receiving the facility which is done on a weekly, bi-weekly or on monthly basis in equal instalments as agreed upon with the MFI. At the time of this study, individuals in a particular group followed a weekly repayment schedule whilst clients outside the group serviced their loans on a bi-weekly or even monthly basis. The group loan was for a maximum period of four months and maximum period of six months for individual loans. Loan repayments are undertaken during group meetings in the presence of all members by the credit officer. Because of this, there is the motivation to pay regularly to avoid public ridicule. The credit officer visits individuals who have taken loans for repayments as well.

\subsubsection{Interest Rates}

Interest rates varied substantially among the MFIs. The interest rates charged from the data gathered ranged between 3.5 to 6 percentages per month translating into $42 \%$, and $72 \%$ respectively per annum. The interest rates were relatively high compared to that of the commercial banks. Despite the high interest rates it has been revealed from the study that the women entrepreneurs still went for subsequent loans to keep their businesses running. This confirms the assertion that commercial banks shy away from granting loans to SMEs.

\subsubsection{Reasons why Beneficiaries took Loans from Multiple Sources}

From the field survey, about $32 \%$ of the respondents took loans from other sources apart from the MFI that they were operating with at the time of the study. The sources of the loan received included cooperative society, other MFIs, friends and family members. According to the respondents, the additional loans were used to expand their businesses as the MFI loan was not sufficient. Others used the loan to pay for the MFI loan as the interest rates are high and incomes generated are marginal. This corroborates the assertion that MFIs are in business to generate higher profits, thereby exploiting their clients instead of helping them grow their businesses. On the other hand, some respondents used the additional loans to pay school fees and other household expenses.

\section{Conclusions}

The business profile and entrepreneurial characteristics of women owned Small and Medium Enterprises (SMEs) in the Tamale Metropolis has been studied and presented. From the study, it was observed that, the level of education of the participants was generally low; over $69 \%$ of the respondents had no formal education, $20 \%$ had primary education, $9.5 \%$ had secondary and $1 \%$ had tertiary education. Also, it was observed that ninety-seven respondents 
representing $54.2 \%$ of the enterprises were managed by the entrepreneurs' themselves whiles only $7.8 \%$ of the enterprises were run by the owner and other non-family employees. Furthermore, petty trading accounted for more than $86 \%$ of the main economic activities undertaken by the respondents while only $4 \%, 3 \%, 4 \%$ and $2.5 \%$ were involved in agro processing, bakery, dress making and hair dressing respectively. The study also found that MFIs charge high rates ranging between $42 \%$ and $72 \%$ per annum, which has the potential to pluck their customers (SMEs) into a vicious cycle of poverty instead of helping them grow their businesses and alleviating their poverty.

\section{References}

Akintoye, I. R. (2006). Enhancing the performance of the Informal Sector for the Economic Development of Nigeria: A Case Study of Lagos State. International Journal of Social Sciences, 5(1), 100-112.

Akintoye, I. R. (2008). Reducing Unemployment through the Informal Sector: A Case Study of Nigeria. European Journal of Economics, Finance and Administrative Sciences, 11, 97-106

Alhassan, A. E., Hoedoafia, A. M. \& Braimah, I. (2016). The Effects of Microcredit on Profitability and the Challenges of Women Owned SMEs: Evidence from Northern Ghana. Upcoming in: Journal of Entrepreneurship and Business Innovation, 3(1).

Aryeetey, E., Harrigan, J., \& Nissanke, M. (2000). Economic Reforms in Ghana: The Miracle and the Mirage. Oxford: James Currey and Accra: Woeli Publishing Services.

Bacchetta, M., Ernst, E., \& Bustamante, J. P. (2009). Globalization and Informal Jobs in Developing Countries, World Trade Organization Publications, Geneva, Switzerland. [Online] Available: https://www.wto.org/english/res_e/booksp_e/jobs_devel_countries_e.pdf (April 1, 2015)

Carsamer, E. (2009). Access to Credit by SMEs in Ghana: Does the type of business matter? Social Science Today. Winneba: Jim Waler Light and Salt Publishers.

Garcia-Bolivar, O. E. (2006). Informal economy: is it a problem, a solution or both? The perspective of the informal business. The Berkeley Electronic Press, Berkeley, USA. [Online] Availabale: http://www.bg-consulting.com/docs/informalpaper.pdf (February 10, 2015)

Ghadoliya, M. K. (2000). Empowering Women through Self-Help Groups. New York: World Bank.

Goetz, A. M., \& Sen Gupta, R. (1994). Who Takes the Credit: Gender Power and Control over use in Rural Credit Programs in Bangladesh. World Development, 24(1), 45-63. http://dx.doi.org/10.1016/0305-750X(95)00124-U

GSS (2005). Population Data Analysis Report; Socio-Economic and Demographic Trends, Vol. 1 UNFPA funded Project (GHA/01/P07) Undertaken by Ghana Statistical Service. 
GSS (2005). Population Data Analysis Report; Socio-Economic and Demographic Trends, Vol. 1 UNFPA funded Project (GHA/01/P07) Undertaken by Ghana Statistical Service.

GSS (2008). Ghana Living Standards Survey: Report of the Fifth Round (V), (Accra). [Online] Available: http://www.ircwash.org/resources/ ghana-living-standards-survey-report-fifth-round-glss-5 (March 15, 2015)

GSS (2012). 2010 Population and Housing Census. Summary report of final results. [Online] Available:http://www.statsghana.gov.gh/docfiles/2010phc/Census2010_Summary_report_of_ final_results.pdf (May 5, 2015)

International Labour Organisation (2000). Employment and social protection in the informal sector. First Item on the Agenda, Committee on Employment and Social Policy, 277th Session, GB.277/ESP/1/1.

Kantor, P. (2001). Promoting Women's Entrepreneurship Development based on Good Practice Programmes: Some Experiences from the North to the South. Geneva: ILO. [Online] Available:http://www.ilo.org/wcmsp5/groups/public/---ed_emp/---emp_ent/documents/public ation/wcms_113762.pdf (June 7, 2015)

Kayanula D., \& Quartey, P. (2000). The Policy Environment for Promoting Small and Medium Enterprise in Ghana and Malawi. Finance and Development Research Programme Working Paper Series no. $15 . \quad$ [Online] Available: http://www.seed.manchester.ac.uk/medialibrary/IDPM/working_papers/archive/fd/fdwp15.pd f (January 20, 2015)

Kiraka, R. N., Kobia, M., \& Katwalo, A. M. (2013). Micro, Small and Medium Enterprise Growth and Innovation in Kenya: A Case Study on the Women Enterprise Fund. ICBE-RF Research Report No. 47/13.

Kiraka, R. N., Kobia, M., \& Katwalo, A. M. (2013). Micro, Small and Medium Enterprise Growth and Innovation in Kenya: A Case Study on the Women Enterprise Fund. ICBE-RF Research Report No. 47/13.

Marcucci, P. N. (2001). Jobs, Gender and Small Enterprises in Africa and Asia: Lessons drawn from Bangladesh, the Philippines, Tunisia and Zimbabwe. Geneva: ILO. [Online] Available:

http://www.oit.org/wcmsp5/groups/public/@ed_emp/@emp_ent/documents/publication/wcm s_113775.pdf (June 12, 2015)

Mayoux, L. (2005). Micro-finance and the Empowerment of Women: A Review of Key Issue, Social Finance Unit. IFAD publication. [Online] Available: http://www.ilo.org/wcmsp5/groups/public/---ed_emp/documents/publication/wcms_117993.p df (May 19, 2015)

MoFEP. (2014). The Composite Budget of the Tamale Metropolitan Assembly for the 2014 Fiscal Year. [Online] Available: www.mofep.gov.gh (September 9, 2014) 
National Board on Small Scale Industries Portal (2013). Micro and Small Scale Enterprises. [Online] Available: http://www.nbssi.org/AboutUs.aspx?PageId=16 (April 6, 2014)

Organization for Security and Cooperation in Europe (OSCE) (2006). Small and Medium Sized Enterprises: Development and Promotion, Best-Practice Guide for a Positive Business \& Investment Climate. Vienna: OSCE, (Chapter 7).

Osei-Boateng, C., \& Ampratwum, E. (2011). The Informal Sector in Ghana. Friedrich Ebert Stiftung.[Online] Available: http://library.fes.de/pdf-files/bueros/ghana/10496.pdf (June 4, 2015)

Roomi, M. A., \& Parrott, G. (2008). Barriers to Development and Progression of Women Entrepreneurs in Pakistan. Journal of Entrepreneurship, 17(1), 59-72. doi: 10.1177/097135570701700105

Stevenson, L., \& St-Onge, A. (2005). Support for Growth-oriented Women Entrepreneurs in Ethiopia, Kenya and Tanzania: An Overview Report. Geneva: ILO. [Online] Available: http://www.afdb.org/fileadmin/uploads/afdb/Documents/Policy-Documents/GOWE\%20Tanz ania.pdf (April 12, 2015)

Teal, F. (2002). Background Information on the use of Dataset: Regional Project On Enterprise Development (RPED) Ghana Manufacturing Sector Survey Waves I-V, Centre for the Study of African Economies, Institute of Economics and Statistics, University of Oxford, St. Cross Building Manor Road, Oxford, OX1 3UL.

Voulgaris, F., Asteriou, D., \& Agiomirgianaki, G. (2003). The Determinants of Small Firm Growth in the Greek Manufacturing Sector. Journal of Economic Integration, 18(4), 817-836. http://dx.doi.org/10.11130/jei.2003.18.4.817

World Bank (2001). World Development Report 2000/01: Consultations with the Poor. Washington: World Bank. [Online] Available: http://siteresources.worldbank.org/INTPOVERTY/Resources/335642-1124115102975/15551 99-1124138866347/jamaica.pdf (May 2, 2015)

Yamane, T. (1967). Statistics: An Introductory Analysis (2nd ed.). New York: Harper and Row, (Chapter 7).

\section{Copyright Disclaimer}

Copyright for this article is retained by the author(s), with first publication rights granted to the journal.

This is an open-access article distributed under the terms and conditions of the Creative Commons Attribution license (http://creativecommons.org/licenses/by/3.0/). 